\title{
ASSESSING THE ECONOMIC IMPACT ON DEVELOPING COUNTRIES AND ITS IMPLICATIONS FOR POLICY
}

\section{Richard Jolly*}

Recent increases in oil prices have had such profound effects on the world economy, actual and potential, that in many areas we are only just beginning to grasp the implications. Moreover, the inevitable uncertainties over the course of future prices mean that the exact magnitude of the changes involved are a matter of debate - and often the debate over the statistics diverts attention from the broad implications of what is involved. This paper is an attempt to emphasise the broad economic issues, by presenting a framework within which some of the main statistics can be summarised, the implications analysed and some options for policy, national and in ternational, explored.

The main thrust of argument is that the oil price increases have in the broadest of terms improved world income distribution between the rich countries and the Third World (benefiting some poor countries within the Third World as well as some rich ones) but at the same time worsened income distribution between Third World countries, to the particular detriment of some of the poorest countries, whose weak performance in terms of growth and distribution over the previous decade was already of very serious concern. In terms of long run action, international and national policy should now attempt to build further and more fundamental changes in world economic relationships on these initial changes, rather than seek to reverse them, especially by introducing measures which will help to reduce world poverty and support broad-based development. In the short and medium run, the "staggering disequilibrium" of the current situation is such that a variety of actions is urgently required - particularly measures by both the developed and oil exporting countries to encourage and facilitate recycling of oil revenues directly and indirectly to Third World countries in ways which benefit the hardest hit countries and the poorest groups within them.

* Richard Jolly is Director of the Institute of Development Studies. 
ASSESSING THE ECONOMIC IMPACT ON DEVELOPING COUNTRIES AND SOME POLICY SUGGESTIONS

\section{The Magnitude of the Economic Changes Involved}

From January 1970 to January 1974 , oil prices rose approximately six and a half times, of which about a four and a half-fold increase took place over the preceding 12 months. The World Bank estimated in mid-January 1974 that these additional revenues of the 11 oil exporting countries from higher oil prices will in 1974 exceed 1973 total revenue by some $\$$ US 65 billion. Of this, some $\$$ US 55 billion is estimated to come from developed countries, the remaining $\$$ US 10 billion from less developed countries. ${ }^{1}$

The increase in export earnings of the Third World oil exporting countries from oil price increases in one year alone is almost as great as total Third World export earnings ( $\$ 74$ billion, including oil) two years earlier. As a shift in world income distribution, it is difficult to think of any change of comparable magnitude and significance arising from an increase in the price of a single item of world trade. It is in this sense that many argue that the oil price increases mark a watershed in world trading relations. It is without doubt a watershed in relations between the oil producing countries and the rest of the world. It may also prove to be a watershed in its psychological (and political) repercussions on thinking elsewhere in the Third World about world trading relationships. This may be the real significance of the "Declaration on the Establishment of a New International Economic Order" and the "Programme of Action", issued at the conclusion of the Special Session of the United Nations General Assembly held in April.

\section{The Impact on Third World Countries}

The impact on individual countries - and on the different groups

\footnotetext{
1 These estimates refer only to the direct effects of higher prices of petroleum imports, not the indirect effects of the higher prices of oil-based products, such as fertilizers or polymers. See the paper by Frank Ellis for further details and estimates. Note also that this paper concentrates on the effects of the oil price increases. Readers should not assume however that these are the only import price increases causing concern to the Third World. The UNCTAD secretariat estimates that as a group, the Third World countries will be hit harder in 1974 by increases in the prices of manufactures and even the bulk of the gains from higher food import prices will accrue to developed countries.
} 
within them - will be the resultant of a number of effects, short run and longer run. Much emphasis has understandably been given to the balance of payments effects but in terms of particular sections of the population, especially those in poverty, the repercussions following price increases of oil-based or oil-related products (especially fertilisers, small-scale diesel irrigation pumps, cooking fuel and transportation) may be more significant.

The impact on the poorest countries and on the poorest groups within countries is particularly important because these are the sections of the Third World whose position was already serious before the oil price increases. Over the 1960s, the rate of growth of per capita income in the poorest countries was under half that of the middle income or rich countries (see Table 3), and at the same time in some of them, most notably India, income distribution appeared to worsen.

\section{The Balance of Payments Effects}

Clearly higher oil prices benefit generally the 11 oil exporting countries and hit to a greater or less extent the oil importing countries. Several sets of estimates are available identifying the magnitudes of these direct effects. ${ }^{2}$

Tables 1 and 2 attempt to group the Third World countries gaining and losing from the oil price increases by continent and broad income category - using the World Bank classification which divides countries into the rich, middle income, poor and very poor.

A Third World country has been listed as hardest hit if it is a net oil importer with no major offsetting gains in trade (as estimated in a paper by the Ministry of Overseas Development of 11 June 1974). ${ }^{3}$

The 11 oil exporting gaining countries had a total (1971) population of about 250 million, of which 176 million were in countries

2 See also the paper by Frank Ellis in this Bulletin.

3 Submitted to the U.K. Parliamentary Select Committee on Overseas Aid and Development, whose report "The Oil Crisis and Third World Development:

Implications for United Kingdom Policy" is in press and will be available from H.M.S.O., Atlantic House, Holborn Viaduct, London EC1 1BN. 
ASSESSING THE ECONOMIC IMPACT ON DEVELOPING COUNTRIES AND SOME POLICY SUGGESTIONS

classified in 1971 as "very poor" (Indonesia and Nigeria), 54 million in countries classified as poor (Iraq, Iran and Algeria), 11 million in a middle income country (Venezuela) and 11 million in the five rich, now very rich countries (Saudi Arabia, Kuwait, Abu Dhabi, Qatar and Libya). According to the World Bank estimates, about half the additional oil revenues in 1974 will accrue to these five very rich countries - and about one-tenth to the two very poor ones.

\section{TABLE 1}

Populations of OPEC member countries grouped by level of income and continent (Population: millions in 1971)

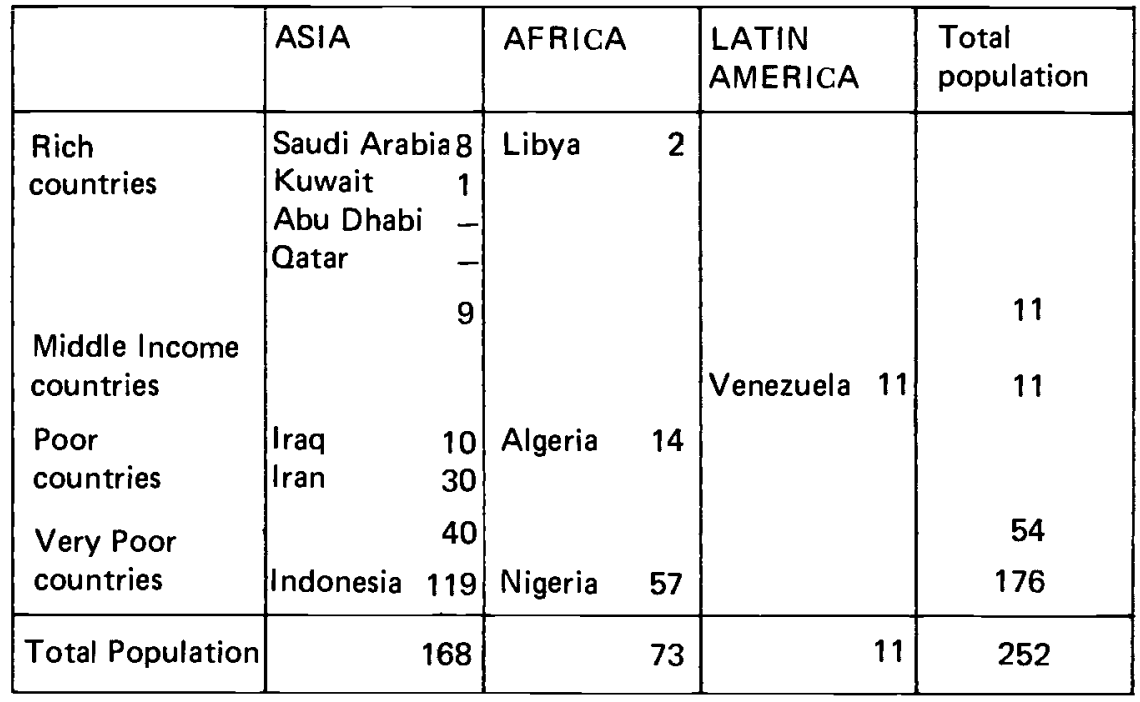

Country classification

Rich

Middle income

Poor

Very poor
Per capita income US $\$ 1970$

1500 and above

$440-1490$

$160-430$

150 or less

Source: Level of per capita income and population in 1971 from World Bank At/as, 1973 
ASSESSING THE ECONOMIC IMPACT ON DEVELOPING COUNTRIES AND SOME POLICY SUGGESTIONS

TABLE 2

Populations of oil importers hardest hit by oil price increases, grouped by level of income and continent (Population: millions in 1971)

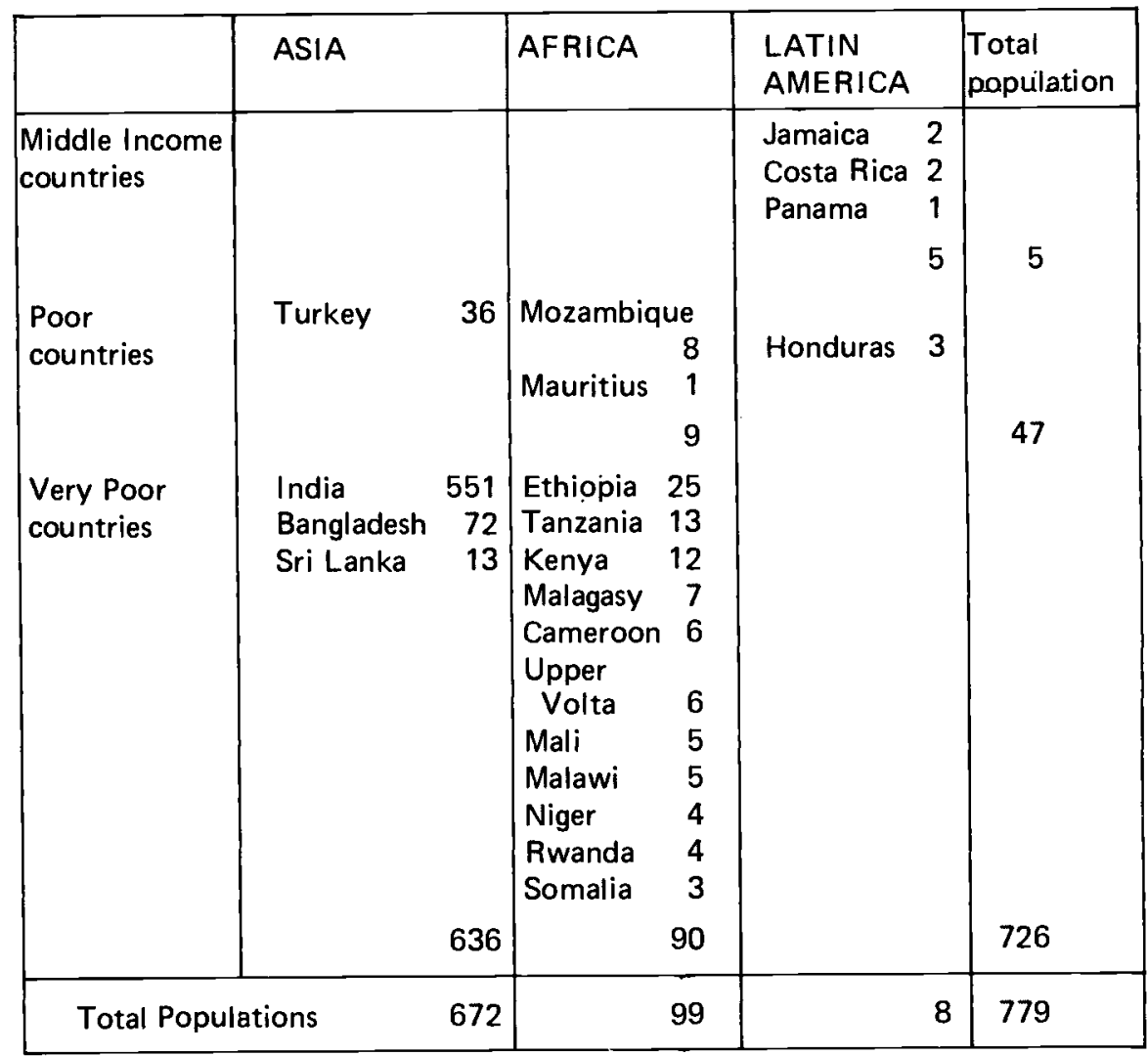

Oil importers hardest hit are the countries of middle and low per capita incomes without major offsetting trade gains or military assistance as estimated from tables submitted by the Ministry of Overseas Development to the U.K.

Parliamentary Select Committee on Overseas Aid and Development, whose report is in press. (N.B. as ODM pointed out, all such lists involve important elements of judgement).

Source: Level of per capita income and population in 1971 from World Bank Atlas, 1973. 
ASSESSING THE ECONOMIC IMPACT ON DEVELOPING COUNTRIES AND SOME POLICY SUGGESTIONS

\section{TABLE 3}

Impact of oil price increases on different country groups of the world economy (Per capita income levels and growth rates by main country groups with total income and populations)

Estimated impact of oil price changes 1974 and 1975

\begin{tabular}{|c|c|c|c|c|c|c|c|c|}
\hline \multirow[b]{2}{*}{$\begin{array}{l}\text { Country } \\
\text { group }\end{array}$} & \multirow{2}{*}{$\begin{array}{l}\text { Per capita } \\
\text { income } \\
\text { (SUS 1970) }\end{array}$} & \multirow{2}{*}{$\begin{array}{c}\text { Per capita } \\
\text { growth } \\
1960.70 \\
\text { (\% p.a.) }\end{array}$} & \multirow{2}{*}{$\begin{array}{l}\text { Total } \\
\text { GNP } 1970 \\
\text { (\$US b) }\end{array}$} & \multirow{2}{*}{$\begin{array}{c}\text { Total } \\
\text { population } \\
1970 \\
\text { (miltion) }\end{array}$} & \multicolumn{2}{|c|}{ Countries clearly gaining } & \multicolumn{2}{|c|}{$\begin{array}{l}\text { Countries of middle and } \\
\text { low income hardest hit }\end{array}$} \\
\hline & & & & & Number & $\begin{array}{l}\text { Population } \\
\text { (1971 million! }\end{array}$ & Number & $\begin{array}{c}\text { Population } \\
\text { (1971 million })\end{array}$ \\
\hline Rich & 2790 & 4.4 & 2570 & 920 & 5 & 11 & - & - \\
\hline Middle Income & 870 & 4.5 & 270 & 310 & 1 & 11 & 3 & 5 \\
\hline Poor & 300 & 3.2 & 155 & 520 & 3 & 54 & 4 & 47 \\
\hline Very poor & 120 & 1.8 & 230 & 1930 & 2 & 176 & 14 & 726 \\
\hline Total & 880 & 4.1 & 3225 & 3680 & 11 & 252 & 21 & 779 \\
\hline
\end{tabular}

Source: Columns 1-4, calculated from World Bank At/as, 1972. Columns 5-8 from Table 1 and 2.

In contrast, the countries hardest hit within the Third World appear to come primarily from the poor and very poor group, and predominantly from the latter. The three hardest hit countries of Asia, India, Bangladesh and Sri Lanka, are all countries classified as very poor and in 1971 had a total population of 636 million. In addition at least 11 African countries classified as very poor are badly hit, with a combined 1971 population of 90 million.

The incidence of Third World countries gaining and losing is put into broader perspective in Table 3, which summarises the changes from oil price increases in relation to 1970 levels of income and population and growth of per capita income over the previous decade. In terms of numbers of countries and the size of population affected, distribution within the world economy appears to have worsened. The very poor group of countries which are hit have in total over four times the population of the very poor countries which have gained.

An important reason why the (short run) impact in 1974 and 1975 of the oil price increases is concentrated on a relatively limited number of less developed countries is that in many other countries export earnings and foreign exchange reserves have been built up in the last few years from the boom in commodity prices. It follows, however, that the number of countries hit severely and the extent of their need may increase after 1975 to the extent that commodity 
prices fall and foreign exchange reserves decline in response to a downturn in activity and imports by the industrialised countries - of which there have already been signs. The risk of a deterioration in world prices is particularly great for commodities like copper, tin and bauxite, for which world demand is especially sensitive to the level of investment activity in the industrialised countries.

For some countries, in the short and medium run, an inflow of financial resources from the oil-exporting countries, or an increase in their demand for the countries' exports, could more than of fset the unfavourable balance of payments effects. The orders of magnitude given at the beginning of this paper suggest that proportionately only about a fifth of the additional oil revenues need be "recycled" via the Third World to more than offset in aggregate the additional costs of higher oil imports. ${ }^{4}$ (The latter are estimated to be $\$$ US 10 billion; a fifth of the additional \$US 65 billion of oil revenues would be $\$$ US 13 billion).

Nevertheless, in absolute terms even \$US 13 billion is an enormous sum. It would need considerable enterprise and organisation to achieve recycling even of this magnitude, particularly when the historical ties and existing institutions mostly emphasise links in other directions.

Moreover, even if recycling in aggregate is achieved, the pattern of recycling flows of export orders and investment from the oil-exporting countries into the rest of the Third World may differ considerably from the pattern of countries hardest hit by balance of payments problems arising from the incidence of oil price increases.

There is thus a double need. First, to ensure that a sufficient degree of recycling takes place, almost certainly well beyond what will take place without special measures, international and national. Second,

\footnotetext{
4 In addition there will be the higher costs of other imports, particularly of oil-based products but of manufactures in general, the prices of which have been rising rapidly with inflation. The net effects of these are difficult to estimate but have already raised aggregate non-OPEC Third World foreign exchange requirements considerably.
} 
ASSESSING THE ECONOMIC IMPACT ON DEVELOPING COUNTRIES AND SOME POLICY SUGGESTIONS

to ensure that the pattern of trade, investment and financial flows generated by the recycling provides adequate support to the hardest hit countries.

\section{Price Increases of Oil-based Products}

In addition to the overall balance of payments effects, the price increases of oil and oil-based products relative to other prices is likely to have major consequences for the pattern of development and of income distribution within countries.

Clearly the impact needs to be traced through in the particular context of the major countries involved. Some conclusions from a World Bank assessment on the impact of higher oil prices in the Asian region may indicate something of what is involved.

"At the new prices, petroleum remains quite competitive with other forms of energy. Nevertheless, the economics of energy production and use are obviously much affected. Hydroelectric power is now an economic substitute up to roughly double the level of capital costs previously considered economic. Rural electrification is now preferable to diesel tubewells up to two or three times the previously economic capital cost. Obviously, coal extraction becomes much more economical and investment plans should be accordingly re-oriented.

The share of fuel costs in road transport operating costs may increase from about 10 to about $25-30$ per cent before taxes. The consequent 15-20 per cent increase in road transport costs might, in many cases, improve the competitiveness of the railways which use two to four times less energy per ton mile, and which in several countries can rely on cheaper energy sources (coal, electricity).

The quadrupling of petroleum prices would very roughly double the cost of fertiliser production, and similarly affect those of petrochemicals, in particular of synthetic fibres and of rubber. Thus, the long-term cost of urea production is now over \$US 100 per ton. However, given the shortage of capacity, the price is likely to remain at the present level of $\$$ US $175-200$ per ton (\$US 430 per nutrient-ton) during the next several years, until new Middle Eastern capacity comes into production"'. 
ASSESSING THE ECONOMIC IMPACT ON DEVELOPING COUNTRIES AND SOME POLICY SUGGESTIONS

It is not easy to assess in general terms the effects of these price changes on the prospects for growth and distribution in all the countries affected. In many respects, the impact on the cost of fertiliser, rural energy and transport can do little to help and much to harm rural development, whether it is development among the richer or the poorer members of the rural community.

Exceptions are possible of course. One important exception arises from the increased attractiveness which natural products will now have over oil-based synthetics (e.g. pyrethrum over DDT) - which is a reminder of the need to redirect and support technological research in these directions, and to encourage activities which would expand trade and production of such commodities.

Even if there is an overall decline in a country's output, some factors may act to improve income distribution in favour of the poorer groups. If, for instance, a decline in food production is concentrated among fertiliser-using large farmers, food prices may increase and thus possibly agricultural incomes of smaller farmers. But however favourable these partial effects on rural income, they are unlikely to offset the disastrous general consequences of a reduction of Third World food supply, particularly in 1974 conditions, with many countries already hard hit by drought.

\section{A Framework for Policy}

As regards the long-term, the crucial issue is to see the oil price increase as a major move broadly in the right direction, even if excessively rapid, and grotesquely unbalanced in its effects. This is so both inasmuch as the bargaining position of Third World countries in trade relations may improve in the future as a result of the lead given by the oil exporters; and insofar as the price increase has beneficial long-term technological and distributional effects in favour of the poorer groups within countries, particularly poor countries. ${ }^{5}$

5 These favourable results do not uniformly follow from the oil price increases but in several respects they may and - if the oil revenues are used aright, particularly by the richer oil-exporting countries - they could follow in much greater measure. 
ASSESSING THE ECONOMIC IMPACT ON DEVELOPING COUNTRIES AND SOME POLICY SUGGESTIONS

It would without any doubt be much better for such moves to have taken place as part of a concerted strategy for reforming world economic relationships, especially the structure and prices of world trade and the distribution of income which results from it. But as with many other major events in economic and social reform the first moves are often precipitate. The real issue, now that the terms of trade for one set of countries have been so dramatically changed, is how future changes in world economic relationships can be progressively undertaken in a coordinated and, if possible, mutually agreed manner.

In the short run, the extent to which the impact on non-oil Third World countries is relieved or exacerbated will primarily depend on the extent to which:-

(i) special credit facilities are made available, internationally;

(ii) the industrialised countries can alter, individually or in concert, their national patterns of aid, investment, trade and financial flows in favour of Third World hardest hit oil countries;

(iii) differential pricing arrangements for oil (in one form or another) are introduced in favour of Third World oil importing countries;

(iv) the oil-exporting countries and the developed countries increase their imports from the Third World or jointly find ways to recycle oil revenues to Third World countries via investment, loans or aid.

A number of measures of the first type are at present under discussion including an IMF oil facility (Witteveen), IMF special drawing rights, the sale of World Bank bonds to oil exporting countries, the United Nations Coordinating Mechanism for Emergency Relief and Special Fund, various oil producer funds and bilateral agreements. The EEC countries have proposed a scheme whereby they would contribute $\$ 500$ million, other industrialised countries $\$ 1000$ million and the oil producing countries $\$ 1500-\mathrm{a}$ total of $\$ 3$ billion possibly to be channelled through the UN Coordinating Mechanism. At the time of writing, most of these 
approaches are still under discussion and, given the fluidity of the situation, it is impossible to make any definitive assessment.

Nevertheless one must emphasise that (a) the total sums under discussion begin to look just about adequate for 1974 but seriously inadequate for 1975 and later, (b) that for some hardest hit countries the likely provision still falls far short of the estimated deficits in the balance of payments for 1974 let alone for later years, (c) the proposals are so far primarily short-term measures, and (d) with the sharp reduction expected in the growth rate of the industrialised countries in 1974 and 1975 , the growth rate of their imports will also be greatly reduced. This in turn will reduce both the volumes and prices of most exports from the Third World, thus exacerbating their balance of payments problems, especially those which have recently benefitted from the higher commodity prices.

The second approach appears to have been less explored, even though in overall impact is it likely to be limited in relation to the magnitude of the problem, especially given the balance of payments pressures which the industrialised countries will themselves be experiencing. Nevertheless, in selective areas a shift in the pattern of traditional aid, investment, trade and financial flows could be an important addition to other measures.

The third approach could be very helpful though currently it seems to be ruled out by OPEC. It would have the possible disadvantage of encouraging oil-intensive sources of energy in countries with access to cheap oil (though this could be avoided with offsetting internal taxes).

The fourth approach quantitatively is potentially of the order of magnitude and has the scope to deal with the problems. Morever, it would be along lines required to reinforce moves towards a long-run reconstruction of the world economy as is more generally needed.

The small size of their populations and the magnitude and the rapidity of the increases in oil revenues means that in many of the richer oil-exporting countries it will be impossible to absorb all the revenues internally or spend all the reserves as imports, at least for some years. The impact on other Third World countries will thus 
ASSESSING THE ECONOMIC IMPACT ON DEVELOPING COUNTRIES AND SOME POLICY SUGGESTIONS

primarily depend on the extent of recycling as measured by the magnitude and direction of:-

flows of investment funds, into real or portfolio investments within the less developed countries;

flows of development assistance from the oil-exporting countries, whether concessionary or not, whether direct or via regional investment banks;

flows of short-term funds (or purchases of gold).

As regards all of these, there are as indicated strong institutional arrangements built up over many years which will mean that unless special measures are taken, the great bulk of the additional revenues are likely to flow back directly to financial or industrial centres of Western Europe, Eastern Europe or the United States. Nevertheless, the Third World countries would greatly benefit (and the industrialised countries lose little) if an increased share of the revenues were to be "recycled" via the Third World countries. Oil revenue investments in Third World countries or orders for exports from them would stimulate Third World activity, and, in turn, stimulate further trade with the industrialised countries. There is no obvious reason for believing that any or all developed countries would do less well from the triangular trade stimulated by such recycling arrangement than they would from bilateral arrangements (though the types of goods involved and the particular links in the trading and financial chain might be different). The Third World would, however, gain substantially. 